\title{
PELATIHAN PEMBUATAN MEDIA VIDEO PEMBELAJARAN BERBASIS WINDOWS+G DALAM UPAYA EDUKASI TENAGA PENDIDIK DI KOTA SURABAYA PADA MASA PANDEMI COVID-19
}

\author{
Oleh: \\ Dian Novita ${ }^{1}$, Bertha Yonata ${ }^{2}$, Rusmini $^{3}$, dan Sri Poedjiastoeti ${ }^{4}$ \\ Jurusan Kimia, Fakultas Matematika dan IImu Pengetahuan Alam \\ Universitas Negeri Surabaya \\ diannovita@unesa.ac.id
}

\begin{abstract}
Abstrak
Salah satu dampak dari Covid-19 terhadap pendidikan di dunia adalah sekolah, madrasah, pondok pesantren, dan universitas ditutup secara luas. UNESCO pada 4 Maret 2020 menyarankan dilaksanakan pembelajaran daring/jarak jauh dan membuka platform pendidikan yang mampu dijangkau oleh peserta didik. Hal ini memerlukan kemampuan yang yang sesuai, salah satunya adalah penggunaan aplikasi tangkap layar (screen recorder) pada sistem wondows. Untuk itu diperlukan pelatihan bagi guru-guru yang belum mempunyai kemmapuan tersebut guna membantu pembelajaran yang dilakukan selama masa pandemic. Pelatihan ini dilakukan ke 25 orang guru MGMP Kimia Kota Surabaya dengan beberapa tahapan, yaitu pelatihan daring melalui zoom, diskusi daring melalui zoom dan WAG, serta pengumpulan tugas. Dari pelatihan yang dilakukan diperoleh informasi pemahaman dan kemampuan guru yang sangat baik jika dilihat dari hasil tugas yang dikumpulkan. Dari respon peserta diperoleh informasi bahwa $80 \%$ peserta merasa mudah dalam membuat video dengan cara Windows+G, 93,3\% berencana menggunakannya untuk membuat video, dan 100\% peserta akan menularkan hasil pelatihannya ke rekan kerja yang lain. Data lain yang diperoleh adalah diperoleh persentase skor $86,7 \%$ terhadap kemenarikan materi pelatihan; persentase skor $91,1 \%$ terhadap kompetensi narasumber, persentase skor $84,4 \%$ terhadap durasi waktu pelatihan; dan persentase skor $93,3 \%$ terhadap kesesuaian materi terhadap tugas guru di sekolah.
\end{abstract}

Kata kunci : pelatihan media video, windows+g, guru MGMP kimia

\begin{abstract}
One of the effects of Covid-19 on education in the world is that schools, madrassas, Islamic boarding schools and universities are widely closed. UNESCO on March 42020 suggested that online / distance learning be carried out and opened an educational platform that was accessible to students. This requires the appropriate capabilities, one of which is the use of a screen capture application on the Windows system. For this reason, training is needed for teachers who do not yet have the capability to assist the learning carried out during the pandemic period. This training was conducted for 25 teachers of the Surabaya City Chemistry MGMP with several stages, namely online training through zoom, online discussion through zoom and WAG, and assignment submission. From the training carried out, it was obtained that the teacher's understanding and ability were very good when viewed from the results of the collected assignments. From the participants' responses, information was obtained that $80 \%$ of participants found it easy to make videos using Windows+G, 93.3\% planned to use them to make videos, and $100 \%$ of participants would pass on the results of their training to other colleagues. Other data obtained were a percentage score of $86.7 \%$ on the attractiveness of the training material; the percentage score of $91.1 \%$ on the competence of the resource persons, the percentage score of $84.4 \%$ on the duration of the training; and the percentage score of $93.3 \%$ on the suitability of the material to the work of teachers in schools.
\end{abstract}

Keywords: video media training, windows $+g$, chemistry MGMP teachers

\section{PENDAHULUAN}

Tidak bisa dipungkiri bahwa semua pihak yang menjalani perkuliahan daring mengalami kepanikan baik guru dan siswa sekalipun. Masalah teknis menjadi salah satu kendala dari sekian banyak kendala dan problem dalam proses belajar mengajar secara daring Untuk mengatasi hal tersebut, salah satu alternatif yang bisa dilakukan oleh tim adalah memberikan pelatihan yang mengatasi kendala dasar dari mengajar daring yaitu membuat media pembelajaran berdasarkan aplikasi tangkap layar atau dapat juga disebut dengan screen recorder. Aplikasi ini dipilih karena merupakan aplikasi yang cukup mudah karena tidak perlu melakukan install software baru di laptop atau HP yang akan digunakan. Aplikasi ini sudah terinstal langsung terutama pada PC yang berbasis Windows yang umum digunakan guru, yaitu Windows+G. Dengan berlatih melakukan kegiatan berdasarkan aplikasi tangkap layar selanjutnya diharapkan para guru dapat melakukan dan mempraktekkan pembelajaran yang menarik, dapat melatih pengetahuan dan keterampilan bagi siswa, dan dapat meningkatkan motivasi dan hasil belajar siswa. Untuk menjaring pemahaman awal guru tentang pemahaman berdasarkan aplikasi tangkap layar, maka diberikan soal kuis terlebih dulu. Dengan demikian 
dapat diketahui titik berat aspek-aspek yang perlu mendapat penekanan dalam kegiatan PKM. Para guru juga diharapkan memiliki antusiasme yang tinggi dalam mengikuti kegiatan pelatihan karena dapat menunjang peningkatan keprofesionalannya.

Terbatasnya dana bagi guru dalam meningkatkan keprofesionalannya ikut memberikan andil yang berarti, sehingga tidak berlebihan bila disimpulkan bahwa jumlah guru yang profesional amat kurang. Oleh karena itu sudah selayaknya peningkatan kompetensi dan mutu dijadikan prioritas utama pada masingmasing guru. Guru merupakan kunci keberhasilan sebuah lembaga pendidikan. Guru adalah sales agent dari sebuah lembaga pendidikan yaitu sekolah. Keberhasilan pengajaran guru dengan kompetensi profesional yang kuat akan sangat mempengaruhi citra lembaga pendidikan tersebut. Oleh karena itu sumberdaya guru ini harus dikembangkan baik melalui pendidikan dan pelatihan serta kegiatan lain agar kemampuan profesionalnya lebih meningkat, karena dengan meningkatnya kompetensi profesional guru akan mempengaruhi hasil belajar peserta didiknya.

Berdasarkan analisis situasi di atas, maka perlu dilakukan penyelesaian masalah dengan melihat skala prioritas yang dilakukan dengan segera dan diharapkan mampu meningkatkan mutu pendidikan, yaitu: Pelatihan Pembuatan
Media Video Pembelajaran Berbasis Windows+G dalam Upaya Edukasi Tenaga Pendidik di Kota Surabaya Pada Masa Pandemi Covid-19.

\section{METODE}

Dengan mengacu pada prioritas permasalahan yang dihadapi, penyelesaian masalah yang ditawarkan melalui kegiatan pengabdian kepada masyarakat ini dilakukan dengan langkah-langkah sebagai berikut.

1. Tahap persiapan: tim pengabdian melakukan koordinasi dengan pihak mitra sasaran, menyusun modul pelatihan serta menyusun kuis dan angket.

2. Tahap pelaksanaan dengan langkah-langkah: 1) menyampaikan materi tentang pelaksanaan tangkap layar/screen recorder dengan aplikasi Windows $+G$, 2) penyajian menggunakan metode diskusi, kegiatan mencoba aplikasi, tanya jawab, dan penyelesaian kuis.

3. Tahap evaluasi, tim memberikan angket untuk mendapatkan umpan balik keterlaksanaan kegiatan pengabdian dan dilanjutkan dengan analisis hasil angket, dan pembahasan sesuai dengan masukan dari peserta.

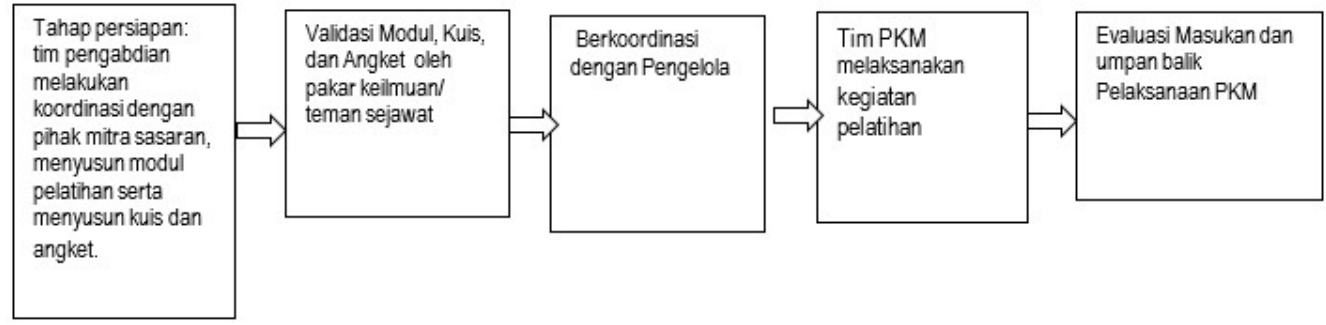

Gambar 1 Alur Kegiatan Pengabdian

\section{HASIL DAN PEMBAHASAN}

Tim pengabdian melakukan koordinasi dengan pihak mitra sasaran, menyusun modul pelatihan serta menyusun kuis dan angket. Koordinasi dengan ketua MGMP Kimia Kota Surabaya dilakukan dengan mendata perwakilan guru kimia yang akan mengikuti pelatihan. Hal ini dilakukan untuk memfokuskan kegiatan agar terlaksana dengan baik. Tindak lanjut dari pelatihan ini adalah peserta yang mengikuti pelatihan diharapkan dapat melakukan diseminasi ke rekan guru di sekolah masing-masing.

Pelaksanaan dilakukan secara daring dan disepakati dengan platform Zoom dan platform WAG dengan tahapan seperti pada tabel 1 . 
Tabel 1 Jadwal Pelaksanaan Pelatihan

\begin{tabular}{|c|c|c|c|}
\hline No. & Hari / Tanggal & Kegiatan & $\begin{array}{l}\text { Plaform / } \\
\text { Pelaksana } \\
\end{array}$ \\
\hline \multirow[t]{6}{*}{1} & \multirow[t]{6}{*}{12 September 2020} & 07.30-08.00 WIB Join Zoom & \multirow[t]{6}{*}{ Zoom } \\
\hline & & 08.00-08.30 WIB Pembukaan & \\
\hline & & 08.30-10.00 WIB Penyampaian Materi & \\
\hline & & 10.00-11.30 WIB Diskusi dan pelatihan & \\
\hline & & $\begin{array}{l}11.30-12.00 \text { WIB Penugasan dan } \\
\text { pengisian respon }\end{array}$ & \\
\hline & & 12.00-12.15 WIB Penutupan & \\
\hline 2 & $13-25$ September 2020 & Latihan mandiri dan diskusi kelompok & WAG kelompok \\
\hline 3 & 28 September 2020 & Pengumpulan Tugas & Link gform \\
\hline
\end{tabular}
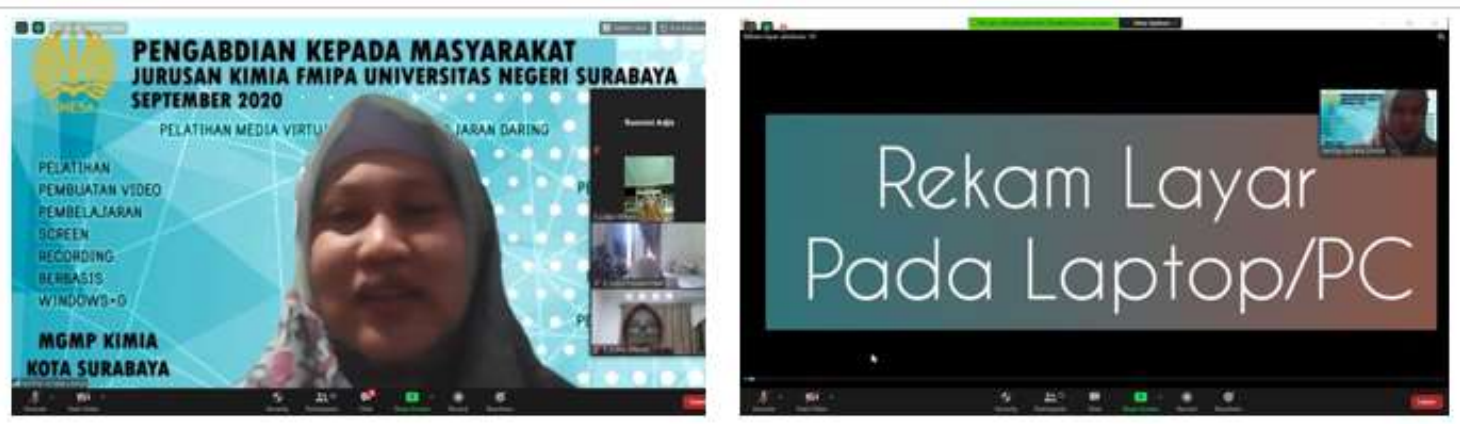

Gambar 1 Pemberian Materi Pelatihan

Modul video disampaikan ke peserta dalam bentuk tayangan di platform Zoom sata pelatihan dan dalam bentuk link file sehingga peserta dapat mencermati kembali setelah pelatihan. Setelah pemberian materi pelatihan dilakukan diskusi terkait materi yang telah disampaikan. Peserta diminta untuk mulai mencoba aplikasi yang telah disampaikan untuk dapat mendiskusikan lebh lanjut terkait kesulitan yang mungkin dihadapi.

Tim memberikan angket untuk mendapatkan umpan balik keterlaksanaan kegiatan pengabdian dan dilanjutkan dengan analisis hasil angket, dan pembahasan sesuai dengan masukan dari peserta. Sebelum pelatihan ditutup peserta diminta untuk mengisi angket respon untuk mengetahui respon peserta terhadap pelatihan. Berikut hasil yang diperoleh:

Tabel 2. Respon Peserta Pelatihan

\begin{tabular}{|c|l|c|}
\hline No. & \multicolumn{1}{|c|}{ Pertanyaan } & Respon \\
\hline 1. & $\begin{array}{l}\text { Apakah bapak ibu } \\
\text { menggunakan video } \\
\text { pembelajaran selama } \\
\text { pandemi ini? }\end{array}$ & \\
\hline 2. & $\begin{array}{l}\text { Apakah bapak ibu } \\
\text { menggunakan video }\end{array}$ & Video YT $=$ \\
& pembelajaran dalam bentuk & $40 \%$ \\
& PPT suara $=$ \\
& PPa? (boleh pilih lebih dari & $60 \%$ \\
\hline
\end{tabular}

\begin{tabular}{|c|c|c|}
\hline & satu) & \\
\hline 3. & $\begin{array}{l}\text { Apakah bapak ibu membuat } \\
\text { sendiri video tersebut? }\end{array}$ & Tidak=53,3\% \\
\hline 4. & $\begin{array}{l}\text { Apakah bapak ibu sudah } \\
\text { pernah } \\
\text { Screen Recording Berbasis } \\
\text { Windows-G seperti ini? }\end{array}$ & Belum $=93,3 \%$ \\
\hline 5. & $\begin{array}{l}\text { Bagaimana } \\
\text { yang bapak ibu gunakan } \\
\text { dengan cara Windows-G } \\
\text { seperti? }\end{array}$ & Mudah $=80 \%$ \\
\hline No. & Pertanyaan & Respon \\
\hline 6. & $\begin{array}{l}\text { Apakah bapak ibu } \\
\text { berencana menggunakan } \\
\text { Screen Recording Berbasis } \\
\text { Windows-G untuk membuat } \\
\text { video selanjutnya? }\end{array}$ & $Y a=93,3 \%$ \\
\hline 7. & $\begin{array}{l}\text { Menularkan hasil pelatihan } \\
\text { kepada rekan kerja yang } \\
\text { lain? }\end{array}$ & $Y a=100 \%$ \\
\hline No. & Pertanyaan & Respon \\
\hline 8. & $\begin{array}{lll}\text { Menurut Anda } & \text { materi } \\
\text { pelatihan ini menarik } & \end{array}$ & $86,70 \%$ \\
\hline 9. & 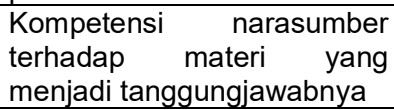 & $91,10 \%$ \\
\hline 10. & $\begin{array}{l}\text { Durasi waktu untuk kegiatan } \\
\text { tatap muka melalui zoom }\end{array}$ & $84,40 \%$ \\
\hline
\end{tabular}




\begin{tabular}{|c|l|c|}
\hline 11. & $\begin{array}{l}\text { Durasi waktu untuk } \\
\text { menyelesaikan tugas-tugas } \\
\text { pelatihan }\end{array}$ & $84,40 \%$ \\
\hline 12. & $\begin{array}{l}\text { Terkait dengan pekerjaan } \\
\text { saya, materi pelatihan ini }\end{array}$ & $93,30 \%$ \\
\hline 13. & $\begin{array}{l}\text { Materi/Topik yang Anda } \\
\text { harapkan untuk kegiatan } \\
\text { pelatihan di masa akan } \\
\text { datang }\end{array}$ & $\begin{array}{c}\text { Pembuatan } \\
\text { animasi; } \\
\text { pembelajaran } \\
\text { online; } \\
\text { praktikum di } \\
\text { pembelajaran } \\
\text { online }\end{array}$ \\
\hline
\end{tabular}

Dari tabel 2 diperoleh data bahwa $80 \%$ peserta merasa mudah dalam membuat video dengan cara Windows $+G, 93,3 \%$ berencana menggunakannya untuk membuat video, dan $100 \%$ peserta akan menularkan hasil pelatihannya ke rekan kerja yang lain. Data lain yang diperoleh adalah diperoleh persentase skor $86,7 \%$ terhadap kemenarikan materi pelatihan; persentase skor $91,1 \%$ terhadap kompetensi narasumber persentase skor $84,4 \%$ terhadap durasi waktu pelatihan; dan persentase skor 93,3\% terhadap kesesuaian materi terhadap tugas guru di sekolah.

Pemahaman dan kemampuan peserta terhadap aplikasi yang dilatihan diperoleh dari hasil tugas yang dikumpulkan. Dari 25 peserta yang mengikuti diperoleh data 21 peserta mengumpulkan tugas yang diberikan dengan hasil sangat baik. Peserta mengumpulkan tugas video melalui link unggah file video atau bahkan beberap diantaranya mengunggahnya di channel Youtube untuk disampaikan ke siswa.

\section{SIMPULAN}

Berdasarkan kegiatan pengabdian pada masyarakat yang telah dilakukan, maka dapat disimpulkan bahwa:

1. Pemahaman dan kemampuan peserta terhadap aplikasi yang dilatihan diperoleh dari hasil tugas yang dikumpulkan. Dari 25 peserta yang mengikuti diperoleh data 21 peserta mengumpulkan tugas yang diberikan dengan hasil sangat baik. Peserta mengumpulkan tugas video melalui link unggah file video atau bahkan beberapa diantaranya mengunggahnya di channel Youtube untuk disampaikan ke siswa.

2. Dari respon peserta diperoleh data bahwa $80 \%$ peserta merasa mudah dalam membuat video dengan cara Windows $+G, 93,3 \%$ berencana menggunakannya untuk membuat video, dan $100 \%$ peserta akan menularkan hasil pelatihannya ke rekan kerja yang lain. Data lain yang diperoleh adalah diperoleh persentase skor $86,7 \%$ terhadap kemenarikan materi pelatihan; persentase skor $91,1 \%$ terhadap kompetensi narasumber, persentase skor $84,4 \%$ terhadap durasi waktu pelatihan; dan persentase skor 93,3\% terhadap kesesuaian materi terhadap tugas guru di sekolah.

3. Berdasarkan hasil respon lanjutan dari kegiatan pelatihan ini diperoleh informasi bahwa guru sangat tertarik dalam mengikuti pelatihanpelatihan yang mendukung kinerja yang dilakukan, khususnya dalam pembelajaran daring seperti kondisi pandemi ini. Beberapa pelatihan yang diharapkan adalah pembuatan animasi; pembelajaran online; praktikum di pembelajaran online.

\section{DAFTAR PUSTAKA}

Ariani N dkk, 2010. Pembelajaran Multimedia Di Sekolah. Jakarta: Prestasi Pustakarya.

Daniel,S. 2007. Profesionalisme Melalui Sertifikasi sebagai Upaya Peningkatan Mutu, Kompetensi, Jumlah dan Kesejahteraan Guru/Dosen. Makalah disampaikan pada Dialog Interaktif 2007 Dirjen Dikdasmen Guru/Dosen se JawaTimur. LPPM Kampus C Unair.

Gulo, W. 2004. Strategi Belajar Mengajar. Jakarta: Gramedia Widiasarana Indonesia.

Harian Haluan. 2020. 11 Kecamatan di Sidoarjo Masuk Zona Merah Corona. (https://www.harianhaluan.com/news/detail/92 689/11-kecamatan-di-sidoarjo-masuk-zonamerah-corona. Sumber: Detik.com. dikunjung 16 April 2020.

Kemenkes. 2020. Tentang Novel Coronavirus (NCOV).

https://www.kemkes.go.id/resources/download /info-terkini/COVID-

19/TENTANG\%20NOVEL\%20CORONAVIRU S.pdf). dikunjungi 16 April 2020.

Kementerian Kesehatan RI Direktorat Jenderal Pencegahan dan Pengendalian Penyakit (P2P). 2020. Pedoman Pencegahan dan Pengendalian Coronavirus Disease (Covid 19).

https://www.kemkes.go.id/resources/download /info-terkini/COVID-

19\%20dokumen\%20resmi/REV-

04 Pedoman P2 COVID-

19_\%2027\%20Maret2020_Tanpa\%20TTD.pdf .pdf). dikunjungi 16 April 2020.

Kompas. 2020. FKM UI Ungkap Corona Masuk RI Sejak Januari, Pemerintah: Kenapa Baru Bilang? https://news.detik.com/berita/d4983197/fkm-ui-ungkap-corona-masuk-risejak-januari-pemerintah-kenapa-baru-bilang. Sumber:Farih Maulana Sidik. Dikunjungi 20 April 2020.

Safrizal ZA, Danang Insita Putra, Safriza Sofyan, Bimo. 2020. Pedoman Umum Menghadapi Pandemi Covid 19 Bagi Pemerintah Daerah. https://www.kemendagri.go.id/documents/covi d-19/BUKU_PEDOMAN_COVID19_KEMENDAGRI.pdf) dikunjungi 15 April $20 \overline{2} 0$

Suara Surabaya. 2020. 23 Kabupaten/Kota di Jatim Sudah Menjadi Daerah Terjangkit. https://www.suarasurabaya.net/kelanakota/20 20/23-kabupaten-kota-di-jatim-sudah-menjadidaerah-terjangkit/. Penulis: Denza Perdana. dikunjungi 15 April 2020. 
Suni, Nur Sholikah Putri. 2020. Kesiapsiagaan Indonesia Menghadapi Potensi Penyebaran Corona Virus Disease. https://berkas.dpr.go.id/puslit/files/info singkat /Info\%20Singkat-XII-3-I-P3DI-Februari-20201957.pdf). dikunjungi 15 April 2020.

Surya. 2020. UPDATE Covid-19 Jatim, Rabu 1 April 2020: Kasus Positif Tembus 103, Sembuh 22 Orang,

https://surabaya.tribunnews.com/2020/04/01/u pdate-covid-19-jatim-rabu-1-april-2020-kasuspositif-tembus-103-sembuh-22-orang.Penulis:
Fatimatuz Zahro, Editor: Parmin. dikunjungi 15 April 2020.

WHO. 2020. Pertanyaan dan jawaban terkait Coronavirus.

https://www.who.int/indonesia/news/novelcoronavirus/qa-for-public), dikunjungi 15 April 2020.i 